\title{
APSA Minority Fellows Selected
}

\section{6-97 APSA African American Fellows}

Three exceptional students were selected as the APSA's funded African American Graduate Fellows for 199697. They are: Eleanor Mack of Xavier University; Tresa Rice of John Carroll University; and LaJoice Billings of the University of Wisconsin at Madison.

Six other talented African American students were selected as non-funded fellows. They are Frances Henderson of Syracuse University; Sherri McFarland of the University of Central Florida; Terrance Taylor of Morgan State University; Shamicka Fulson of East Central University; Kimala Price of Tulane University; and Sekou Franklin of Santa Clara University.

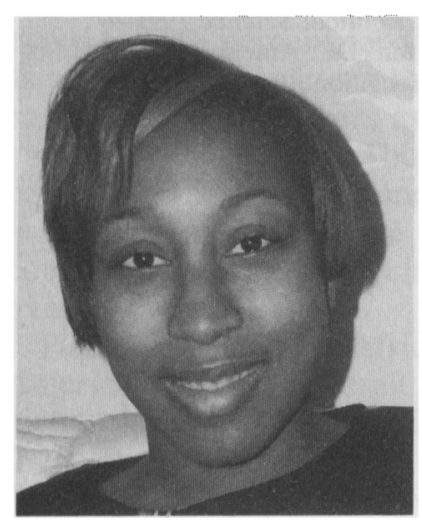

Tresa A. Rice

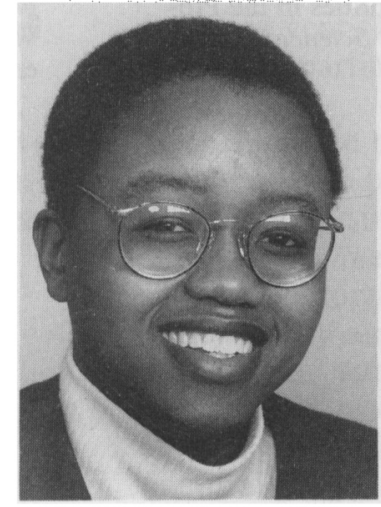

Kimala Price

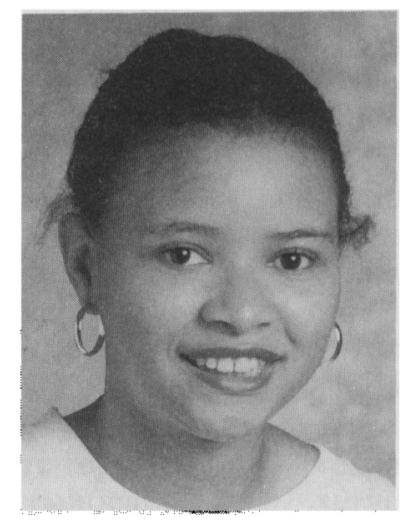

Eleanor Mack

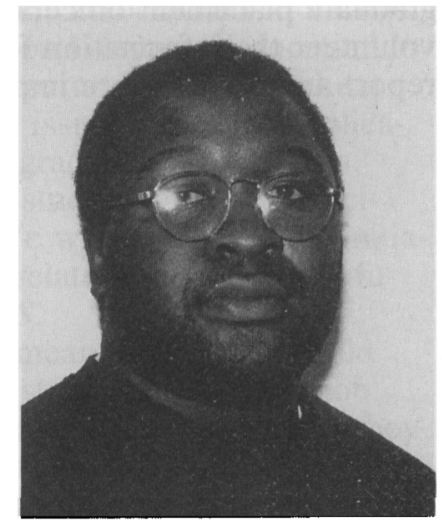

Terrance Taylor

\section{6-97 APSA Latino Graduate Fellows}

Victor Ramon Mendiola was selected as the APSA's funded Latino(a) Graduate Fellow for 1996-97.

Nine other excellent students were selected as non-funded Latino(a) Graduate Fellows. They are Vanna Gonzalez of UCLA;

Ricardo Ramirez of UCLA; Diego Von Vacano of Wesleyan University; Angel Toldeo-Lopez of the University of Puerto Rico; Juan Verde of Boston University; David A.M. Wallerstein of the University of Washington; Christina del Castillo of California State University at San Marcos; Michael Garcia of the University of Colorado; and Alexander Hernandez of Florida International University.

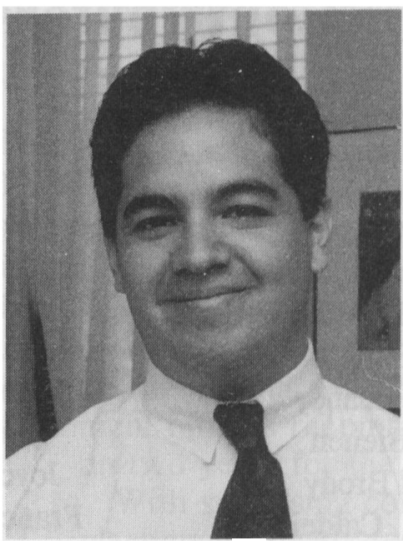

Victor R. Mendiola, Jr.

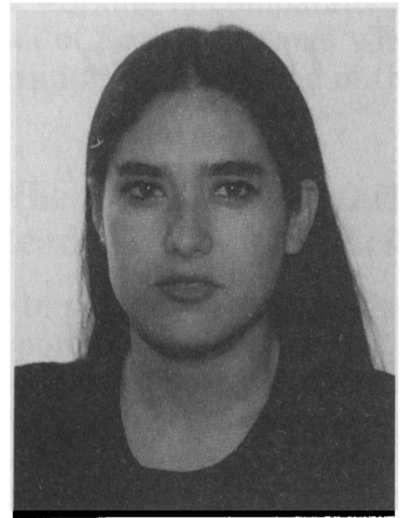

Vanna A. Gonzales

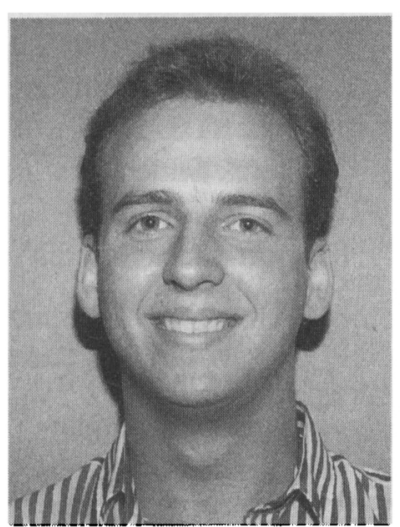

Angel A. Toldeo-Lopez

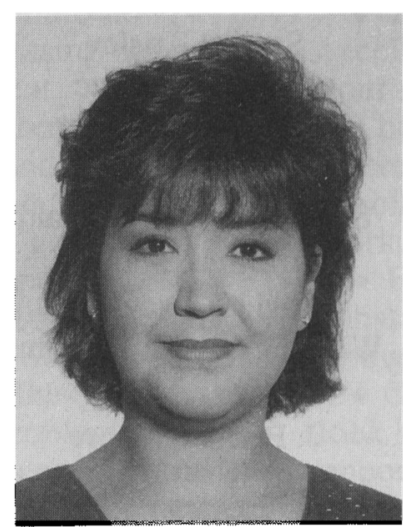

Christina del Castillo

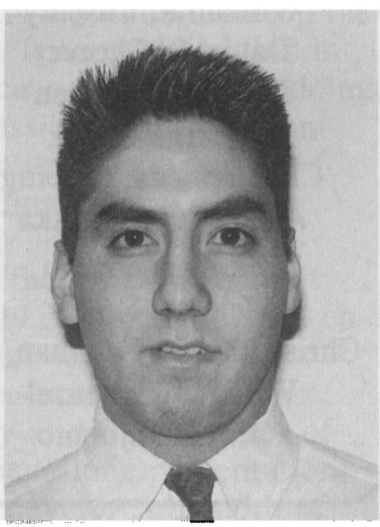

Michael Garcia 


\section{6-97 APSA Native American Graduate Fellows}

Joely De La Torre of Northern Arizona University was selected for the Native American nonfunded fellowship.

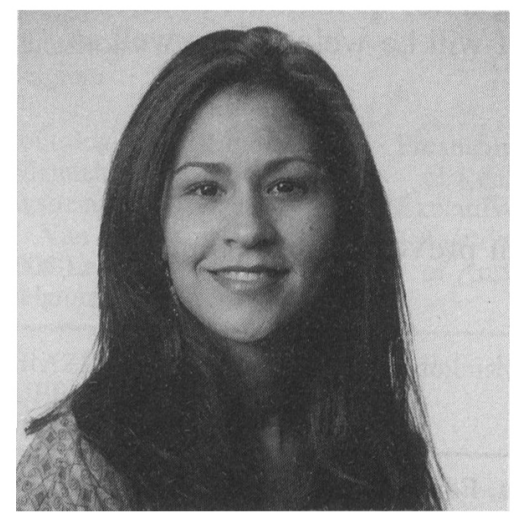

Joely De La Torre

\section{UVA and William S. Paley Foundation Support Ralph Bunche Summer Institute}

John Casteen, President of the University of Virginia, and Provost Peter Low announced that the University of Virginia would contribute $\$ 35,000$ in support of the Ralph Bunche Summer Institute for 1996. UVA's contribution, combined with a gift from the William $\mathrm{S}$. Paley Foundation and support from the American Political Science Association, will enable 10 students to participate in the program this summer.

The Institute, now in its tenth year, is a five-week academic program for African-American rising seniors to introduce them to the world of graduate study and encourage application to Ph.D. programs.

President Casteen is making available university resources in order to ensure that the Institute can be held without interruption and to enable the university and APSA to raise outside funds in subsequent years, according to Paula D.
McClain, chair of the Department of Government, who has energetically spearheaded efforts to support the Institute and secure its continuation.

The Institute, hosted in two locations during the past nine years-in Baton Rouge, Louisiana, and in Atlanta, Georgia-now moves to Charlottesville, Virginia. In partnership with APSA, founding Director Jewell Prestage led the Institute in its first four years at Southern University and Louisiana State University. Professor Peter Zwick provided leadership for this effort at LSU.

The Institute moved to Atlanta, Georgia, in 1990 where a consortium of schools sponsored the program. Led by Professors Lois Moreland and Jeanne Meadows of Spelman College, the Atlanta Consortium additionally included Emory University, Morehouse College, Georgia State University, and Clark Atlanta University. For the past two years the two courses offered by the Institute have been taught by Institute Director Meadows of Spelman and Professor Alan Abramowitz of Emory. In 1996 the Institute will be led by UVA Professor Steven Finkel who will also teach the quantitative component of the program.

Students who have participated in this program over the past nine years have reported improvement in their analytical, writing, and quantitative skills. Most students who attend the Ralph Bunche Summer Institute excel in their senior year and go on to graduate school, many with full graduate fellowships and teaching assistantships. A number of Institute participants have received their masters and $\mathrm{Ph}$.D.'s, and three have already been named assistant professors at the university level.

The Institute has been generously funded by the Ford Foundation, the Coca-Cola Foundation, the U.S. Department of Education, the Graduate School of Emory Uni- versity, the Georgia State University Foundation, the members of APSA, and now the University of Virginia and the William S. Paley Foundation. All participating institutions have enthusiastically contributed faculty time and in-kind gifts that have made the Institute possible. Particularly notable have been the contributions of Spelman College, Emory University, and Georgia State University.

Graduate departments of political science, at their own expense, send recruiters to the Institute to interest the Bunche students in their graduate programs and to invite applications. The Educational Testing Service of Princeton, New Jersey, supports the program by sending a representative to the Institute each summer to help students prepare to take the Graduate Record Examination.

\section{Section News}

\section{Presidency Research Group}

On November 15 and 16, 1995 , Columbia University and the Presidency Research Group, an Organized Section of the American Political Science Association, will cohost a conference at Columbia University on the American presidency: "Presidential Power: Forging the Presidency for the 21st Century." The 35th anniversary of the publication of Presidential Power by Richard Neustadt will serve as the backdrop for the conference, which will assemble junior and senior scholars, including Richard Neustadt, to discuss social science research in the context of presidential performance and effectiveness.

Further conference information can be found at the Presidency Research Group Web page: http:// sunsite.unc.edu/lia/prgnet, where conference registration information will be posted; or call or e-mail Martha Kumar at (302) 328-9498/ kumar-m@toe.towson.edu. 